Esta publicación cientifica en formato digital es continuidad de la revista impresa ISSN-Versión Impresa 0798-1406 / ISSN-Versión on line 2542-3185Depósito legal pp
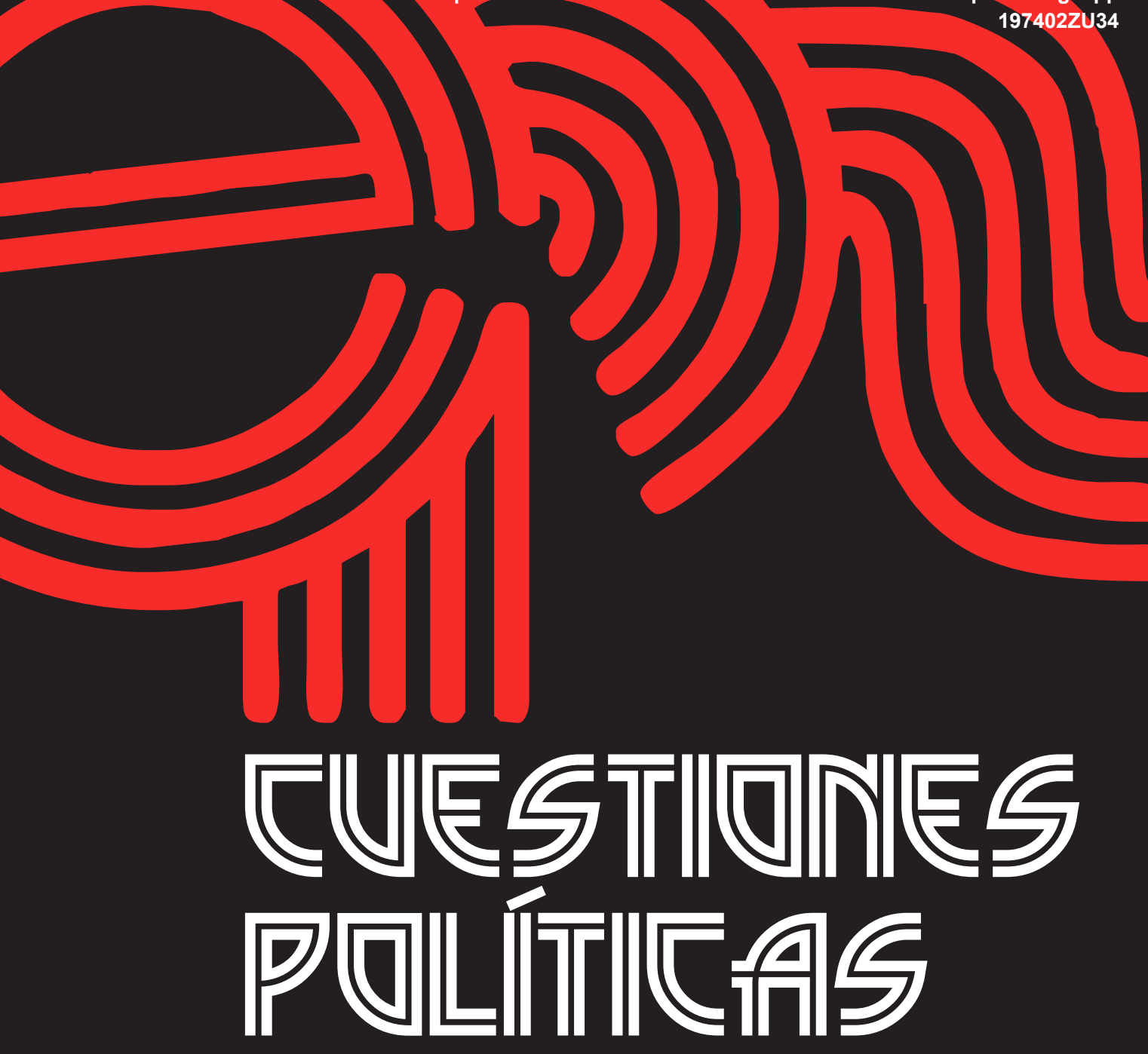

Instituto de Estudios Políticos y Derecho Público "Dr. Humberto J. La Roche" de la Facultad de Ciencias Jurídicas y Políticas de la Universidad del Zulia Maracaibo, Venezuela
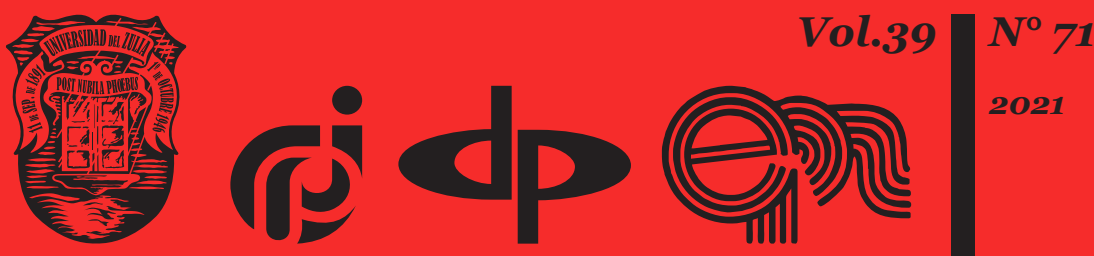


\title{
Methodological foundations of the spatial development of the region: content, conceptual instrument
}

\author{
DOI: https://doi.org/10.46398/cuestpol.3971.51
}

Igor Valerievich Zhilkin *

Aleksandr Yurievich Anisimov **

Irina Anatolyevna Kubrak ***

Anna Victorovna Maslennikova ****

Vladimir Yurievich Melnikov ${ }^{* * * * *}$

\section{Abstract}

Through a methodology of documentary and dialectical basis, in the article, the authors investigate the methodological foundations of the spatial development of the region, through the study of its content and conceptual instrument. In the same way, different points of view on the concept of "region" are presented, the fundamental methodological elements of the formation and organization of the socio-economic development of the region are listed, characterizing the potential of natural resources and the socio-economic development of the municipal districts. Based on this information, the region's place in the social division of labor was determined, the development prospects of the districts were outlined, and the cause-and-effect relationships of the region's socioeconomic indicators were also established. By way of conclusion, everything indicates that the socio-economic development of the region under modern conditions is seen, in the first place, in self-sufficiency. Therefore, your accumulated potential must first be assessed to make a real assessment and then organize a search for the missing resources and funds. The use of a type of strategic management at all levels of management of the political system is the key to a balanced and successful development.

\footnotetext{
* Ph.D. (in Economics) Associate Professor of the Department of Management and Logistics in Transport Samara State University of Railways; Samara, Russia. ORCID ID: https://orcid.org/oooo-0001-96463699

** Ph.D. (in Economics), Associate Professor; Moscow, Russia. ORCID ID: https://orcid.org/oooo0002-8113-4523

*** Ph.D. (in Economics), Associate ProfessorState and Municipal administration ANO IN "Russian New University"; Moscow, Russia. ORCID ID: https://orcid.org/oooo-0001-6820-4948

**** Ph.D. (in Economics) Head of the Department of State and Municipal Administration ANO IN "Russian New University” (ANO IN «Ros NOU»); Moscow, Russia. ORCID ID: https://orcid.org/oooo-00o32090-6080

***** Ph.D. (in Political Sciences), Associate Professor at the Department of Personnel Management at the Russian New University Moscow, Russia. ORCID ID: https://orcid.org/oooo-0002-9934-5628
} 
Igor Valerievich Zhilkin, Aleksandr Yurievich Anisimov, Irina Anatolyevna Kubrak, Anna Victorouna Maslennikova y Vladimir Yurievich Melnikov

834 Methodological foundations of the spatial development of the region: content, conceptual instrument

Keywords: regional economy; region; space economy; spatial development of the region; common economic space; comprehensive development strategy.

\section{Fundamentos metodológicos del desarrollo espacial de la región: contenido e instrumento conceptual}

\section{Resumen}

A través una metodología de base documental y dialéctica, en el artículo, los autores investigan los fundamentos metodológicos del desarrollo espacial de la región, mediante el estudio de su contenido e instrumento conceptual. Del mismo modo se presentan diferentes puntos de vista sobre el concepto de «región», se enumeran los elementos metodológicos fundamentales de la formación y organización del desarrollo socioeconómico de la región, caracterizando el potencial de recursos naturales y el desarrollo socioeconómico de los distritos municipales. A partir de esta información, se determinó el lugar de la región en la división social del trabajo, se delinearon las perspectivas de desarrollo de los distritos y además se establecieron las relaciones de causa y efecto de los indicadores socioeconómicos de la región. A modo de conclusión todo indica que el desarrollo socioeconómico de la región en condiciones modernas se ve, en primer lugar, en la autosuficiencia. Por lo tanto, primero debe evaluarse su potencial acumulado para hacer una evaluación real y luego organizar una búsqueda de los recursos y fondos faltantes. El uso de un tipo de gestión estratégica en todos los niveles de gestión del sistema político es la clave para un desarrollo equilibrado y exitoso.

Palabras clave: economía regional; región; economía espacial; desarrollo espacial de la región; espacio económico común; estrategia de desarrollo integral.

\section{Introduction}

In Russia, in the conditions of the formation of market relations, the role of the regional factor is increasingly manifested, since reforms are carried out within the constituent entities of the federation, which differ significantly from each other in many parameters (Kolmakovaet al., 2018;Kolmakova, 2014; Kolmakovaet al., 2016; Vilner, 2016; Vilner, 2017; Simonova and Efremova, 2016;Bukhvald and Valentyk, 2015; Belomestnov, 2019). In this regard, the number of scientific studies devoted to regional problems is 
constantly increasing, which has led to the allocation of scientific knowledge about the regional economy as an independent branch (Kolmakovaet al., 2018; Kolmakova, 2014; Kolmakovaet al., 2016; Vilner, 2016; Vilner, 2017; Simonova and Efremova, 2016; Bukhval and Valentyk,2015;Belomestnov, 2019;Zubarevich, 2015; Belomestnov and Khardaev, 2017; Manasyan, 2006;Granberg, 2000;Gutmanet al., 2001; Bilchak and Zakharov, 1998; Kazachenko, 2012). The term "regional economy" appeared in the last century. In the early 70 of of the XX century. Pavlenko defined its subject as follows: "This is the specific economy of individual regions, general patterns, factors and problems of their development" (Bilchak and Zakharov, 1998: $35)$. It is necessary to proceed from the fact that, along with general economic problems, the regional economy should include the problems of the development of material production, demography, sociology, and ecology of the region.

In turn, the study of the specifics of the spatial development of the region is impossible without considering the features of the economic space. To date, an appropriate scientific base has been formed for conducting research on the methodological issues of the development of the economic space, including the economic space of the region. However, the conceptual foundations of the spatial economy have not yet been fully identified, and the mechanisms of economic development based on spatial transformations have not been developed. Moreover, there is no common understanding of the key definition - "economic space". Revealing the peculiarities of the concept of "spatial development", determining its place among related terms, allows to form a terminological basis that contributes to the development of a scientifically grounded methodology of spatial development of the region. The key element of the methodology is the approach, within which the strategic planning documents reflecting aspects of the spatial development of the territory should focus on the organization (primarily, structural) space, while setting the criteria for the optimality of this phenomenon (Suvorova, 2019).

Thegrowing interestin the regulation of the sphere of spatial development, due to the change in the state policy of the Russian Federation in the field of regional development and the corresponding change in regulatory legal acts related to strategic planning in the Russian Federation, as well as the transformation of foreign policy conditions and macroeconomic factors, actualizes the study of the methodological foundations of the spatial development of the region, by defining the essential characteristics of a number of key terms, which include the concept of "spatial development". 


\begin{abstract}
Igor Valerievich Zhilkin, Aleksandr Yurievich Anisimov, Irina Anatolyevna Kubrak, Anna Victorouna Maslennikova y Vladimir Yurievich Melnikov

836 Methodological foundations of the spatial development of the region: content, conceptual instrument
\end{abstract}

\title{
1. Literature Review
}

The development of the regional economy as a science did not result in the creation of a generally recognized synthetic theory. Today its state is characterized by a variety of theoretical approaches, increased specialization of research, and the emergence of new directions.

By now, two views on the subject of regional economics have formed in Russia (Kazachenko, 2012). The first considers the regional economy as one of the specific economic sciences that studies the general laws, factors and problems of regional development. Supporters of the second view consider the rational distribution of productive forces to be the basis of the subject of regional economics. However, in this interpretation, the subject of the regional economy is completely absorbed by economic geography (Granberg, 2000; Gutmanet al., 2001; Bilchak and Zakharov, 1998; Kazachenko, 2012).

According to academician Granberg (2000), a new area of economic knowledge is now emerging - spatial economics, which is based on the regional economy. In his opinion, economic geography and the distribution of productive forces as academic disciplines are almost unrelated to the fundamental disciplines of economic education in macro- and microeconomics. The core of economic science and education, according to the researcher, should develop as a three-pole system: macroeconomics, microeconomics, regional (spatial) economics.

In Russia, it is customary to use the term "placement theory". In the English language literature, the term "spatial economics" is used, translated as "spatial economics". The founder of the theory of production location is von (Thünen 1998; Gorkin, 2013). He was not the first researcher to study space as an economic phenomenon, but he was the first to use special methods of analysis to study space.

In general, "space" is understood as an objective reality, one of the main forms of existence of matter, characterized by length and volume, in which the interaction of a set of elements occurs.

Appendix 1 presents approaches to the concept of "space". In all economic studies, "space" basically means a gap between something, a place where something fits, a limited area. Economic geography also considers limited areas, united by some peculiarities (Gorkin, 2013; Voronin and Sharygin, 1998). The study of the economic aspect of the concept of "space" is contained in Appendix2.

Each science, each scientific direction develops in an indissoluble connection with the practical needs and demands of society. The theory of regional science, methods of location and territorial development are closely intertwined with the practical tasks of regional planning and forecasting, 
management, the formation of a regional economic market, the functioning of the social environment. Regional science, as is usually called in market countries, regional studies is, in the opinion of most experts, a field of scientific and educational knowledge that is widely demanded by the time, aimed at studying the specifics of socio-economic, natural, environmental development in relation to integral territorial formations called regions (Granberg, 2000; Gutmanet al., 2001; Bilchak and Zakharov, 1998). In the economic and geographical literature, regions are called a variety of territories, united by some common features:

- groups of countries (for example, the Caribbean or North African region, etc.) - macro-regions.

- region, territory, republic, and their groups - mesoregions.

Less commonly, regions are called territories within a region, territory, republic (microregions).

The gradations of the classification of regions found in Western literature are presented in Appendix 3.

In foreign and domestic literature today, you can find several dozen interpretations of the concept of "region" (Kazachenko, 2012). This diversity is explained by the lack of clarity in the definition of the subject of regional science itself, which, undoubtedly, is one of the reasons for the diversity of directions and methodological conditions in modern research both in Russia and abroad.

The situation created in regional science by the famous American economic geographer Isard (1960) is explained as follows:

As we delve into purely spatial theorizing, the region as a definition disappears altogether and appears only in connection with the specification of the problem. In other words, the "hierarchy" of regions is determined only by a scientific problem. The region is determined by the issue we are studying (1960: 760).

The unity in the interpretation of the concept of "region" among scientists, dealing with regional problems, lies in the fact that almost all of them highlight the following features: limited territory with production content, natural, labor resources; specialization in some kind of activity; characteristic internal and external connections. Then disagreements begin.

The term "region" in most cases is characterized by a large-scale criterion. In theory and practice, it is used to designate fairly large physicalgeographical, economic-geographical, geopolitical and other territorial taxa. In some cases, regions may even unite several lower administrative districts, but this is rather an exception to the general rule.

In Russian economic and economic-geographical science, the term "region" is most often used as a synonym for the concept of "region". 
Igor Valerievich Zhilkin, Aleksandr Yurievich Anisimov, Irina Anatolyevna Kubrak, Anna Victorovna Maslennikova y Vladimir Yurievich Melnikov

838 Methodological foundations of the spatial development of the region: content, conceptual instrument

Historically, the concept of "region" in Russian scientific literature appeared much earlier than the term "region". Back in the 8os-90s of the XIX century, researchers distinguished agricultural areas, industrial areas, etc. In the Soviet period, the regional direction in the organization of the country's productive forces became, due to its vast territories, fundamental, both in theory and practice.

Based on the official terminology adopted in our country, the term "district" was defined quite "rigidly" (Alaev) and was most often associated with the administrative grid, while the term "region" was more elastic (Vituleva, 2014). Over time, in the scientific literature and the media, the term region began to be gradually replaced by the term "region" as more rigorous in the scientific sense.

Interpretations of the concept "region" are presented in Appendix 4.

\section{Methods}

The methodology adopted in this article is of a qualitative type. Qualitative analysis of literature documents was the preferred method in this study. Documentary sources include materials of international scientific and practical conferences, articles, monographs produced in the field of strategy, spatial development of the region, regional economy, economic geography, strategic development of territories, spatial development, as well as official documents of the Government of the Russian Federation that express various positions and interests in the field strategizing the spatial development of the Russian Federation.

During the study, general and special methods of economic and managerial research were used, including analysis and synthesis, induction and deduction, generalization and comparison, methods of logical and comparative analysis, as well as the following applied methods, one of the methods of economic and statistical analysis - method of graphical display of information.

\section{Results and Discussion}

All the numerous interpretations of the concept of "region" we have considered in this article can be conditionally divided into the following groups:

- reproductive, - when it emphasizes the importance of reproductive processes in the region. 
- administrative-territorial, - when it is based on the existing administrative-territorial division of the country's territory or on the factor of controllability of regional development.

- socio-territorial, - when a socio-territorial community is emphasized, and the region is considered as a socio-territorial system.

- territorial-economic, - considers the region as a complex territorialeconomic complex with its resources, production, needs and connections.

- socio-economic system. In this approach, the opinions of the authors differ: some characterize the region with such fundamental features as complexity, integrity, specialization, and manageability; others - in the direction of the development of productive forces, the existing and promising social infrastructure; the third in terms of any properties of the territory within which a certain community of people (society) has developed, which has certain development goals.

Based on the existing modern approaches to the definition of the concept of a region, we believe that it is a spatial holistic, complex socioeconomic system, within which a certain community of people (society) has developed, which has certain governing bodies, which purposefully works to increase the competitiveness of space and the quality of life of people living in the region.

Appendix 5 contains the author's characteristics of the concept of "region".

An important feature of the region is manageability, which is directly related to the administrative - territorial division. And here it is necessary to emphasize that the integrity of the region contributes to a certain extent to manageability, because the administrative and territorial bodies are called upon to ensure the coordination (management) of all elements of the social economy: material production, natural resource potential, infrastructure, labor resources, etc., as well as diverse connections - trade, financial, social, environmental, industrial, which have a certain spatial and temporal stability (Vituleva, 2014; ArzhenovskiyandKiy, 2014; Blaug, 1994;Artobolevsky, 1993).

Appendix 6 provides a description of the principle of "expedient integrity of the region".

Interaction theory explains the regional system and its development as a result of the interaction of various isolated and independent parties, and the conditions of social life. Moreover, the degree of influence of one factor or another on the state and dynamics of the region is its specificity. The founder of this theory is the Russian scientist Kovalevsky (1851-1916) (Dejan and Vujadinović, 2017). 


\footnotetext{
Igor Valerievich Zhilkin, Aleksandr Yurievich Anisimov, Irina Anatolyevna Kubrak, Anna Victorovna Maslennikova y Vladimir Yurievich Melnikov

840 Methodological foundations of the spatial development of the region: content, conceptual instrument
}

The differentiated role of various factors in different regions, changing in time, does not allow building their hierarchical system, since in a given region at the moment one group of factors plays a decisive role, at another time - another, and in another region at the same time - a third. Regionforming factors are presented in Appendix 7.

This list (appendix7) of region-forming factors is universal, suitable for considering regions of any scale. In our case, when considering a microregion, i.e., region within the subject of the federation, the need for a detailed consideration of some factors disappears. For example, we cannot study the socio - economic system of the region, since in our work we only consider the possibility of creating a new region, and not the existing region. The political and geographical factor is considered mainly in the study of macroregions.

There are also different points of view on the tasks and essence of regional policy, theory, and practical ways of its implementation, which is caused by an ambiguous understanding of the very object of regional policy, goals and means of its implementation (Ronald, 2005; Garretsenet al., 2013; Dejan and Vujadinović, 2017).

According to the majority of authors (Arzhenovskiy and Kiy, 2014; Artobolevsky, 1993; Ronald, 2005; Garretsenet al., 2013; Dejan and Vujadinović, 2017), the regional policy of the state is a sphere of activity for managing the economic, social and political development of the country in the spatial aspect, i.e., connected with the relationship between the state and the regions, as well as the regions among themselves.

Regional policy in the Russian Federation is the sphere of activity of state authorities in managing the economic, social and political development of the country in the regional (spatial) aspect. According to some experts, its essence is the implementation of government measures to redistribute resources between regions of the country for the sake of the set goals (Artobolevsky, 1993). At the same time, three levels of spatial relations and interactions can be distinguished: federal, interregional and intraregional.

At the federal level (federal center - regions), regional policy is carried out by federal government bodies. At the interregional level (region - regions), it can be carried out by state authorities of the constituent entities of the Federation in conjunction with regional associations of economic interaction. The intraregional level (regional center - periphery) is provided by state authorities of the subjects of the federation and local self-government bodies (Artobolevsky, 1993).

The main directions of regional policy are presented in Appendix 8.

Regional aspects of demographic, agrarian policy and other measures of state power should also be referred to the directions of regional policy. The 
attitude of the state to each of these areas and the specific measures carried out in them constitute the content of the state's regional policy.

The content of regional policy in almost all developed countries (pursuing an active regional policy) has common features (Artobolevsky, 1993; Walter, 1960; Ronald, 2005; Garretsenet al., 2013):

- development of underdeveloped territories, reconstruction of the economy of depressed industrial regions.

- decentralization of agglomerations and areas of concentration of industrial production.

- the formation of new industrial centers outside of urban settlements, not associated with the existing centers of industry.

Without the implementation of such a policy, imbalances both regionally and throughout the country will increase.

In the works of the world-famous Organization for Economic Cooperation and Development (OECD, 2012), which periodically summarizes the experience of different countries and publishes relevant materials, it is noted that the objects of regional policy in the countries of market economy are various kinds of regional (spatial ) inequality - differences in the level and conditions of life, in employment and unemployment, in the rates of economic development of individual regions, in the conditions of entrepreneurship, etc. Regional policy acts in the form of government intervention in various subsystems of the region, and not only in the economic one (Artobolevsky, 1993; Walter, 1960; Garretsenet al., 2013; Dejan and Vujadinović, 2017; OECD, 2012).

Appendix 9 presents a grouping of traditional tasks of regional policy.

Experts in the field of state regional policy refer to its main elements: economic, structural, investment, budgetary, tax, tariff, institutional, social policy (Artobolevsky, 1993; Walter, 1960;Garretsenet al., 2013; Dejan and Vujadinović, 2017; OECD, 2012), and consider the main features:

- complexity, i.e., focus on all aspects of social life.

- durability, i.e., calculation for the long term.

- conjugation, i.e., coordination with other components of the state strategy.

- centralization, i.e., compliance with the interests of the state as a whole.

- the balance of all elements of the territorial system of the region. 


\footnotetext{
Igor Valerievich Zhilkin, Aleksandr Yurievich Anisimov, Irina Anatolyevna Kubrak, Anna Victorovna Maslennikova y Vladimir Yurievich Melnikov

842 Methodological foundations of the spatial development of the region: content, conceptual instrument
}

Moving on to the consideration of the methodological foundations of the spatial development of the region, based on the world and Russian experience of regional policy, the following fundamental methodological approaches can be singled out.

The methodological foundations of the spatial development of the region are presented in Appendix10.

In modern conditions of a digital market economy, the most important type of management of the activities of regional administrations is the strategic type of management.

A strategy is understood as the development of promising areas of activity, carried out on the basis of a long-term forecast of development and an assessment of real opportunities, taking into account the accumulated potential, on the basis of which the term "strategic management" appeared, which in its most general form is considered as the activities of the relevant bodies for the choice of areas, directions and image actions to achieve longterm goals in a changing external environment.

A brief description of Russia's spatial development strategy is given in Appendix 11.

It should be emphasized that in the modern conditions of the development of the digital economy, more and more attention is paid to the issues of strategic management at all levels of management, which is confirmed by numerous publications of researchers on this topic (Kvint, 2014; Kvint, 2016; Kvint, 2009; Darkin and Kvint, 2016; Plakhotnikova, 2018; Plakhotnikova, 2019; Patova and Plakhotnikova, 2020; Eliseeva, 2018;Plakhotnikovaet al., 2019;Anisimovet al., 2017).

\section{Conclusion}

Thus, among the fundamental methodological elements of the formation and organization of the socio-economic development of the region should include:

- consistency of analysis, decisions, transformations.

- market reorientation of the regional economy.

- taking into account the specifics of the region.

- integration of activities of types, spheres, industries, forms, processes.

- modern innovative activity.

- organization of strategic management. 
Based on these methodological foundations, it is possible to build a framework for the modern socio-economic development of the region and the corresponding management mechanisms.

At the same time, based on world experience, it is necessary to take into account:

- the need for a gradual evolutionary (phased) structural transformation of the regional economy.

- the presence of an extremely close interconnection of the components of the reproduction process in the regional economy.

- the possibility of alternative development options.

- differentiated, local testing of new mechanisms and tools.

The socio-economic development of the region in modern conditions is seen, first of all, in self-reliance. Therefore, you first need to assess your accumulated potential in order to make a real assessment and then organize a search for the missing resources and funds. The scientific position of most authors is based on the need to integrate the potential of all individual parts of the territorial system (industrial complexes, industries, municipalities) into a complex systemic set that ensures the progress of the region.

The interrelationships and merging in the regional economy of resources, advantages, advantages, opportunities and results of the functioning and development of individual territories (cities, districts, villages, townships) qualitatively transform and strengthen the total potential of the region.

The use of a strategic type of management at all levels of management is the key to further successful balanced development.

\section{Annexes}

\section{Appendix 1. Approaches to the concept of "space"}

There are two approaches to the concept of "space". The first assumes the presence of clearly defined boundaries (external and internal), which can change over time. This is a geographic space, which is formed by any factors, such as the requirements of the administrative-territorial structure of the state, but has fixed boundaries. The second presupposes the establishment of an economic (political, legal, cultural and national) space that has not borders of territories, but borders of economic, political, legal, cultural and national interests (Gutmanet al., 2002; Kazachenko, 2012).

It should be borne in mind that any division of space (territory) into regions is rather arbitrary. The need to divide large territorial units into 


\footnotetext{
Igor Valerievich Zhilkin, Aleksandr Yurievich Anisimov, Irina Anatolyevna Kubrak, Anna Victorouna Maslennikova y Vladimir Yurievich Melnikov

844 Methodological foundations of the spatial development of the region: content, conceptual instrument
}

parts is due to the very large differentiation of parts according to many characteristics.

\section{Appendix 2. The economic aspect of the concept of "space"}

Let's consider the concept of «space» in the economic aspect. For economic science, as already mentioned, the boundaries of space are the limits of the action of the main economic flows. It is necessary to highlight the mega, meso, micro and macro levels of space. If we consider the world economic space as a mega-level, then the country's economic space can be defined as a macro-level. The meso-level can be attributed to the economic space of the region, and the micro-level - the space of specific socioeconomic systems.

The Common Economic Space (hereinafter referred to as the CES) is a single structure of the national economy. Within this structure, there is an interaction between the market and the state in space. Therefore, it can be argued that all agents of the economy are united by a single economic space of the country, where the same rules for all are monitored and supported by special state institutions.

The Common Economic Space (CES) presupposes the existence on the territory of the country of a single national currency, a single legislative framework, a single national bank, and uniform conditions for the movement of people and goods across the territory (Huseynov, 2014).

The common economic space underlies the formation of a common economic space (hereinafter referred to as the CES), which implies the achievement of an "equilibrium and balanced economy", approximately the same standard of living throughout the country, income equality, based on the self-sufficiency of regions and budgetary equalization (Arzhenovskiy and Kiy, 2014).

For the first time, a theoretical model of general economic equilibrium in the classical market was developed by the Swiss economist Blaug (1994). From the point of view of Blaug(1994), the total supply of final products in monetary terms should be equal to the total demand for them as the sum of incomes brought by all factors of production to their owners. At the same time, equilibrium is considered achieved only when there is not only an equilibrium of supply and demand, but also an equal well-being of participants in market relations, which implies an increase in the well-being of all participants. These provisions are presented in Figure 1 - a diagram of a single and common economic space. 


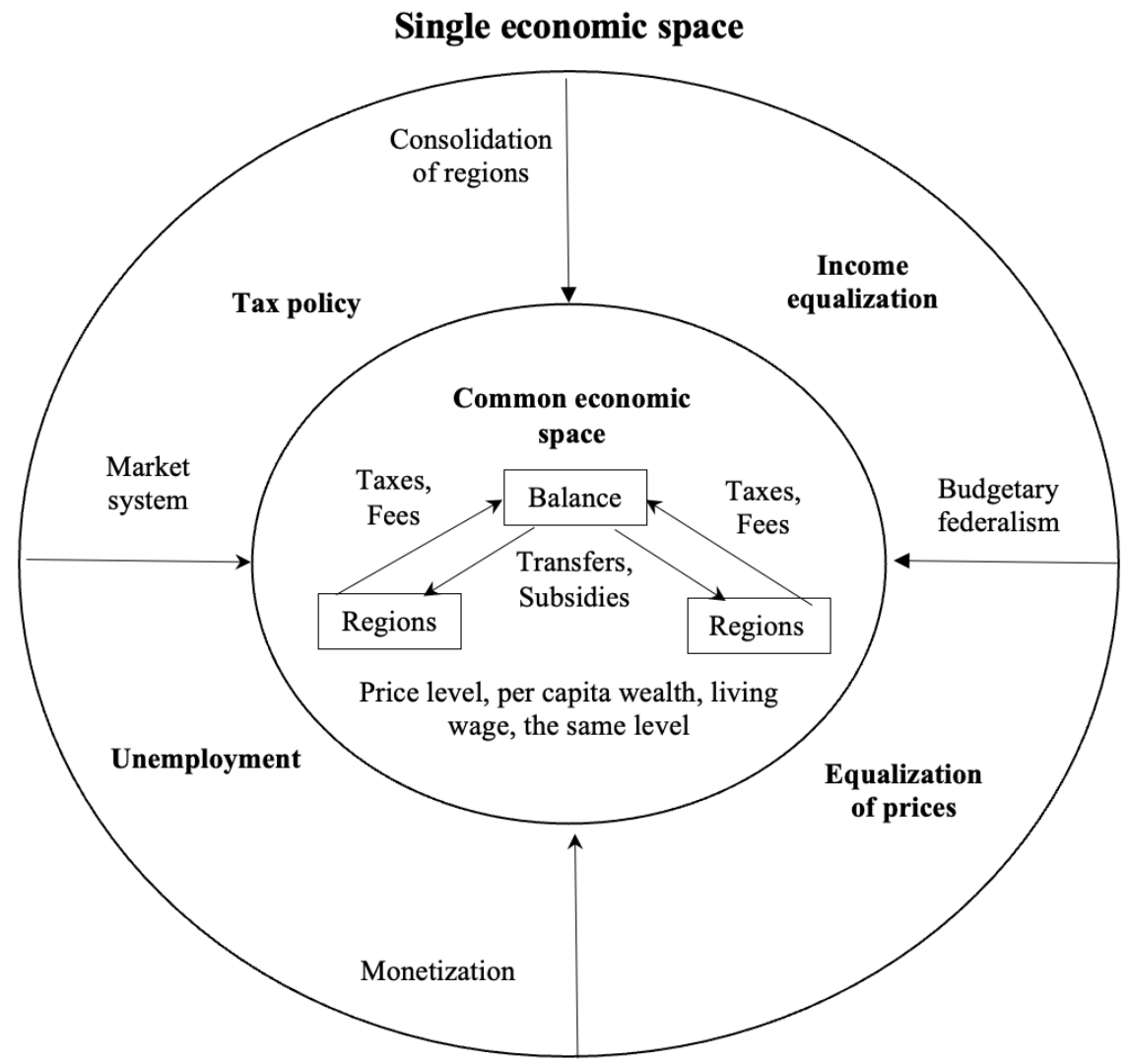

Figure 1. Scheme of a single and common economic space (Huseynov, 2014).

When market mechanisms cease to operate, an imbalance arises in the national economy and government regulation becomes necessary. The role of the state in the economy involves the interaction of the state and the market as two complementary ways of coordinating relations between economic agents and their groups. Thus, it is advisable to consider the market and government regulation as the main regulatory forces for achieving economic equilibrium, and, accordingly, ways to achieve a common economic space.

The mutual influence of the state and the market is realized as follows: the state regulates and stimulates the economy and promotes the organization of 


\footnotetext{
Igor Valerievich Zhilkin, Aleksandr Yurievich Anisimov, Irina Anatolyevna Kubrak, Anna Victorovna Maslennikova y Vladimir Yurievich Melnikov

846 Methodological foundations of the spatial development of the region: content, conceptual instrument
}

society, the economy determines the capabilities and power of the state and forms the economic interests of society (Artobolevskiy, 1993). Maintaining and stimulating competition in the OES is a function of the state. Therefore, even in the theoretical market model, the state plays the most important role in preserving the economic space itself by expressing public interests (Gutmanet al., 2002). Not a single private business, no matter how gigantic it has reached, by its nature can ignore its own interests and assume the interests of the whole society. Any market model is implemented under the influence of both economic and non-economic factors. As the complexity of the economic development of a country increase, the role of non-economic factors increases, since the achievement of CES is not an end in itself, but a means of improving the quality of life of people.

\section{Appendix 3. Grades of classification of regions found in Western literature}

In Western literature, when classifying regions, the following three gradations are most often used (Bilchak and Zakharov, 1998; Kazachenko, 2012; Vituleva, 2014; Gorkin, 2013):

- regions distinguished by single characteristics, that is, taking into account some individual phenomenon (for example, a beet-growing zone). Such regions are sometimes called simple.

- regions distinguished by several characteristics. They reflect a combination or symbiosis of various phenomena (for example, landscape regions in physical geography). These regions are called complex.

- regions covering almost the entire totality of manifestations of human activity within the territory under consideration. They usually reflect the close relationship between natural (natural) and social indicators of the territory.

\section{Appendix 4. Interpretations of the concept of "region"}

By definition Alayev (2014), the term "region" is used quite ambiguously:

- as a synonym for the term "district", hence - regional, i.e., relating to the district, districts.

- to designate comparable taxa belonging to different taxonation systems or to different orders of the same taxonation system.

- to designate any territories that, by their characteristics, do not "fit" the adopted system of territorial division and do not allow them to be designated by other terms.

- to designate territorial taxonomic units of a certain class in a particular taxonation system. 
The concept of "region" is quite clearly defined in official documents as a part of the territory of the Russian Federation, which has a common natural, socio-economic, national-cultural, and other conditions (Potapov, 2016). The region can coincide with the borders of the territory of a constituent entity of the Russian Federation or unite the territories of several constituent entities. In those cases when a region acts as a subject of law, it is understood only as a subject of the Russian Federation (Potapov, 2016).

In the definition of (Bilchak and Zakharov, 1998; Vituleva, 2014; Huseynov, 2014) emphasizes the importance of the factor of controllability of regional development: "A region is a socio-economic spatial integrity characterized by the structure of production of all forms of ownership, concentration of population, workers, any territory that is economically and administratively independent, starting from rural area and ending with large national economic territorial complexes".

A well-known specialist in the field of regional economics Nekrasov viewed the region from a socio-economic standpoint, without considering such a category as "self-government", i.e., administrative division. "Under the region," Nekrasov, - is understood as a large territory of the country with more or less homogeneous natural conditions, and mainly a characteristic direction of the development of productive forces based on a combination of a complex of natural resources with the corresponding established and promising social infrastructure" (Bilchak and Zakharov, 1998; Kazachenko, 2012; Vituleva, 2014).

The importance of reproduction processes on the territory of the region is emphasized by the authors of the book "Fundamentals of the theory of regional reproduction" Marshalova and Novoselov, for whom "the region is not only a subsystem of the country's socio-economic complex, but also a relatively independent part of it with a complete reproduction cycle, special forms of manifestation of reproduction stages and specific features of the course of social and economic processes" (Bilchak and Zakharov, 1998; Kazachenko, 2012; Vituleva, 2014; Gorkin, 2013).

The region is a relatively isolated part of a wider socio-territorial community. The region forms a subsystem of the economy, population, culture, politics and other aspects of social life, organized on the basis of the principles of functioning of a part of the territory"- this is the definition given by Belov (Bilchak and Zakharov, 1998;Kazachenko, 2012; Gorkin, 2013).

In her opinion, the difference between a region and other types of social systems lies in the fact that it is a socio-territorial system. It is the territory that acts as the initial prerequisite for the acquisition by the region of systemic qualities inherent only to it. The cohabitation of people 


\section{Igor Valerievich Zhilkin, Aleksandr Yurievich Anisimov, Irina Anatolyevna Kubrak, Anna Victorovna Maslennikova y Vladimir Yurievich Melnikov \\ 848 Methodological foundations of the spatial development of the region: content, conceptual instrument}

within a common natural - geographical and social space predetermines, on the whole, general conditions for work, life, leisure, etc., hence the approximately equal opportunities for improving personal qualities, forming and meeting material and spiritual needs.

"Region" is a historically evolving compact territorial community that contains physical content, socioeconomic, political and cultural environment, as well as a spatial structure that is different from other regions and territorial units, such as a city or nation (Kazachenko, 2012).

Doliatovsky believes that the region in the modern sense is a complex territorial-economic complex with limited internal resources, its own production structure, and certain needs in connection with the external environment (Bilchak and Zakharov, 1998; Kazachenko, 2012; Vituleva, 2014; Gorkin, 2013).

The region, according to Dergachev and Vardomsky, is always selfsufficient (but not self-sufficient) and distinctive, that is, it has an internal socio-cultural code (Bilchak and Zakharov, 1998; Kazachenko, 2012; Gorkin, 2013).

A universal theoretical interpretation of the concept "region" was given by Alaev. He believes that "a region is a territory that differs from other territories by the totality of its saturating elements and possesses unity, interconnectedness of constituent elements, integrity, and this integrity is an objective condition and a natural result of the development of this territory" (Bilchak and Zakharov, 1998; Kazachenko, 2012; Vituleva, 2014; Gorkin, 2013).

It also considers integrity to be an obligatory element of the region, and the term "region" is defined as a part of the country's territory that has emerged in the process of social (territorial) division of labor, which is characterized by specialization in the production of certain goods and services; community and specific in relation to other territories, the nature of the reproduction process; the complexity and integrity of the economy; the presence of governing bodies that ensure the solution of the tasks facing the region.

\section{Appendix 5. The author's characteristics of the concept "region"}

The integrity of the region means a completely rational use of the natural resource potential of the region, a proportional combination of various industries, the formation of stable intraregional and interregional production and technological ties, the presence of a special community of people with certain traditions, a certain way of life (Vituleva, 2014; Oshchepkov and Kuzmina, 2013). 
The complexity of the region's economy means, first of all, a balance, proportional coordinated development of the region's productive forces. This is such an interconnection between the elements of the economy, when the main national economic function is effectively performed the specialization of the region, there are no significant intraregional disproportions and the region's ability to carry out expanded reproduction within its limits on the basis of available resources remains (Voronin and Sharygin, 1998; Oshchepkov and Kuzmina, 2013).

An indicator of the complexity of the regional economy, - points out Arzhenovskiy (2014), - can be the products of intraregional production consumed in the region; the share of products for cross-industry use; the degree of use of regional resources. Complexity and integrity serve as a prerequisite for the relative isolation of regions within the national economy of the country. It manifests itself in the fact that part of the reproductive ties is limited to a given territory, on this basis, relative independence is formed.

\section{Appendix 6. Characteristics of the principle of "expedient integrity of the region"}

The selection of a region is based on the principle of expedient integrity, determined by a group of region-forming factors. Distinguish, on the one hand, the internal integrity of the region - the formation of its economic complex, the implementation of a single policy, the creation of unified authorities and management, etc., as well as the external integrity of the region - its isolation in relation to other similar regions, to the whole territory, to other territories and their constituent parts.

The development of any region is a contradictory process: uniting centripetal and separating centrifugal forces are simultaneously operating in it. Moreover, any region-forming factor in some specific conditions contributes to the strengthening of the region, and in others - to its degradation and disintegration. It is important to establish the limits beyond which the region-forming factor turns from centripetal to centrifugal.

Region boundaries are dynamic. The long historical process of regional development is characterized by a change in periods of centralization, consolidation of regions by the annexation of new territories and periods of decentralization, reduction of regions by their disintegration into parts and disconnection of territories (Ronald, 2005).

\section{Appendix 7. Region-forming factors}

The researchers distinguish the following factors as region-forming factors: 
Igor Valerievich Zhilkin, Aleksandr Yurievich Anisimov, Irina Anatolyevna Kubrak, Anna Victorovna Maslennikova y Vladimir Yurievich Melnikov

850 Methodological foundations of the spatial development of the region: content, conceptual instrument

- history of development and formation of the region.

- natural conditions and resources.

- ethnic and confessional factors of regionalism.

- the demographic factor of regionalism.

- labor resources of the region.

- $\quad$ state and territorial structure.

- socio-economic system in the region.

- the economic and geographical state of the region.

- the political and geographical factor of regionalism.

\section{Appendix 8. Main directions of regional policy}

Regional policy is an integral part of the national strategy for socioeconomic development and covers the following main areas (Artobolevskiy, 1993):

- determination of the ratio of the moving forces of regional development and ensuring their interaction (public and private sectors of the economy, internal and external factors of the development of the region and means).

- the ratio of national and regional aspects of development, central and regional levels of economic management.

- the rise of the economy of the backward regions and the development of new regions and resources.

- national economic issues (in a multinational state).

- problems of urbanization.

\section{Appendix 9. Group of traditional tasks of regional policy}

The group of traditional tasks includes:

- reconstruction of the economy of old industrial regions and large urban agglomerations by converting defense and civil sectors, modernizing infrastructure, improving the ecological situation.

- overcoming the depressive state of agro-industrial regions, for example, the Non-Black Earth Region, the South Urals, Siberia, the Far East; revival of small towns and Russian villages, restoration of the lost living environment in rural areas, development of local industrial and social infrastructure, development of abandoned agricultural and other land lands. 
- stabilization of the socio-economic situation in regions with extreme natural conditions and predominantly raw materials specialization.

- creating conditions for the revival of small peoples.

- development of interregional, regional and intraregional infrastructural systems (transport, communications, informatics), providing structural changes and efficiency of the regional economy.

- overcoming the excessive lag in the level and quality of life of the population of individual republics and regions and taxonomic units.

\section{Appendix 10. Methodological foundations of the spatial development of the region}

From a scientific point of view, any region should be considered as a complex socio - economic complex, within which a system of connections and dependencies between organizations, enterprises, institutions, population, and governing bodies is specifically formed and manifested in a peculiar way. A region is both a whole (a single economy) and a part (of a national economy). Therefore, the most acceptable and productive scientific approach to the study of phenomena, connections, problems and ways of development in the regions is the system methodology.

Effective management of the socio-economic development of the region is unthinkable without a deep knowledge of certain market laws. Chief among them: the development of production is driven by effective demand and, above all, by the final demand of consumers; production is focused on improving quality characteristics, individualizing the satisfaction of needs, increasing the beneficial effect of using products; competitive manufacturing based on innovation thrives; there is an expansion of the service sector, a certain overflow from the industrial sector into the sphere of various kinds of services (the so-called "serviceization" of social production).

As a result, the economy becomes socially oriented, focused on increasing the efficiency of meeting the needs of society, i.e., the main thing is the market reorientation of the entire economic system of the region, and everything else is the profit of producers, employment of the population, budget revenues, social protection of the poor, etc. - is derived from the main one.

Each region is deeply specific, unique in its own way both economically and in social, geographic, climatic, demographic, ecological and other characteristics. Without knowledge of the specific features of a particular region, any attempt at reform is doomed to failure.

The practice of regional management clearly proves the effectiveness of integration carried out in various forms. There are intra-sectoral, inter- 


\section{Igor Valerievich Zhilkin, Aleksandr Yurievich Anisimov, Irina Anatolyevna Kubrak, Anna Victorovna Maslennikova y Vladimir Yurievich Melnikov \\ 852 Methodological foundations of the spatial development of the region: content, conceptual instrument}

sectoral, territorial, intra-regional, inter-regional and international types. There are also horizontal, vertical, diagonal and combined types of integral structures. There are various classifications of activity integration. It can be distinguished: organizational, economic, financial, industrial, trade, technological orientation of integration and their combinations. Integration allows you to increase the efficiency of functioning of differentiated links and processes and to obtain a specific synergistic effect (Arzhenovskiy and Kiy, 2014; Dejan and Vujadinović, 2017).

The reality of the market system of life is such that only a general increase in the competitiveness of the regional economy can ensure sustainable socio - economic development. It, in turn, consists of the growth of the competitive advantages of individual enterprises, industries, territories and their totality. The most significant factor in increasing competitiveness in the world is considered to be the activation of innovative activities. It is innovations that primarily attract investment, which creates the preconditions for the technical modernization of production, renewal of the range of products, and economic progress. Research and global experience make it possible to recognize the transition to the intensification of innovative activity as one of the key methodological premises of the region's economic development.

\section{Appendix 11. Strategy for spatial development of the Russian Federation until 2025 (summary)}

At present, in Russia, in accordance with the federal law "On strategic planning in the Russian Federation" (Federal Law "On Strategic Planning in the Russian Federation" dated 28.06.2014, No. 172-FZ), a strategy for the spatial development of the Russian Federation for the period up to 2025 has been developed (Strategy of spatial development of the Russian Federation for the period up to 2025. Approved by the order of the Government of the Russian Federation dated 13.02.2019, No. 207-r).

The main objectives of the Strategy are:

- ensuring sustainable and balanced spatial development of Russia.

- reduction of interregional differences in the level and quality of life of people.

- acceleration of economic growth and technological development.

- ensuring national security.

To implement the above goals, the Strategy defines the tasks, principles, priorities, and main directions of the spatial development of Russia, scenarios of spatial development, including the priority (target) scenario, promising centers of economic growth, macroregions, promising economic specializations of the subjects of the Federation, target indicators of the spatial development of Russia. 
As part of the implementation of the Strategy, it is envisaged to increase the accessibility and quality of the main transport, energy, information and telecommunications infrastructure, reduce the level of interregional differentiation in the socio-economic development of the constituent entities of the Federation, reduce intraregional socio-economic differences, expand geography and accelerate economic growth, scientific, technological and innovative development of Russia due to the socio-economic development of promising centers of economic growth.

\section{Bibliographic References}

ANISIMOV, Alexander Yurievich; OBUKHOVA, Anna Sergeyevna; ALEKSAKHINA, Yulia Vladimirovna; ZHAGLOVSKAYA, Anna Valerievna; KUDRA, Andrey Andreevich. 2017. "Strategic Approach to Human Resource Management System Formation in the Organization"In: International Journal of Economic Perspectives. Vol. 11, No. 2, pp.442-448.

ARTOBOLEVSKY, Sergey S.1993. "Regional policy in Russia today: The new role of the state"In: European Planning Studies.Vol. 1, No. 3,pp. 379-382.

ARZHENOVSKIY, Igor Valentinovich;Kiy, M. 2014. Regional economy: textbook. pos. for universities.Nizhegor. state architect. - build. un-t. NNGASU. Nizhny Novgorod, Russia.

BELOMESTNOV, Victor Georgievich. 2019. "Theories of regional economic growth" In: Bulletin of Contemporary Research. Vol. 31, No. 4-19, pp. $10-16$.

BELOMESTNOV, Victor Georgievich;KHARDAEV, K. P. 2017. "On the formation of a regional strategy for socio-economic development in the context of the formation of a new economic policy (on the example of the Republic of Buryatia)" In: Problems of the modern economy. Vol. 1, No. 61, pp. 120-125.

BILCHAK, VasilyStepanovich; ZAKHAROV, Valentin Fedorovich. 1998. Regional economics: monograph. Amber Skaz Publishing House. Kaliningrad, Russia.

BLAUG, Mark. 1994. General equilibrium according to Walras. Economic Theory in Retrospect. Delo. Moscow, Russia.

BUKHVALD, EvgenyMoiseevich; VALENTYK, Olga Nikolaevna. 2015. "Strategic planning and new guidelines for regional development policy in the Russian Federation"In: Economics: yesterday, today, tomorrow. Vol.5, pp.21-41. 
Igor Valerievich Zhilkin, Aleksandr Yurievich Anisimov, Irina Anatolyevna Kubrak, Anna Victorovna Maslennikova y Vladimir Yurievich Melnikov

854 Methodological foundations of the spatial development of the region: content, conceptual instrument

DARKIN, Sergey;KVINT, Vladimir. 2016. The Russian Far East: Strategic Priorities for Sustainable Development). (co-authored). Apple Academic Press. New York, USA.

DEJAN, Šabić; VUJADINOVIC, Snezana. 2017. Regional development and regional policy. Available online. In: https://www.researchgate.net/ publication/324928702_Regional_development_and_regional_ policy. Date of consultation: 20/06/2020.

ELISEEVA, Evgeniya. 2018. The energy management is a key social and environmental strategy in the company. 18th International multidisciplinary scientific GEO conference SGEM 2018, Pp. 855-862. Available online. In:https://sgem.org/sgemlib/spip.php?article13148. Date of consultation: 20/03/2020.

FEDERAL LAW. 2014. “On Strategic Planning in the Russian Federation”. No. 172-FZ. Available online. In: http://base.garant.ru/70684666/. Date of consultation: 20/03/2020.

GARRETSEN, Harry;MCCANNB, Philip;MARTINC, Ron; TYLER, Peter. 2013. "The future of regional policy" In: Cambridge Journal of Regions, Economy and Society.Vol. 6, No. 2, pp. 179-186.

GORKIN, Alexander Pavlovich. 2013. Socio-economic geography: concepts and terms. Dictionary-reference book. Oikumena. Smolensk, Russia.

GRANBERG, Alexander Grigorievich. 2000. Fundamentals of regional economics: textbook for universities. SU HSE.Moscow, Russia. Available online. In: https://publications.hse.ru/books/54926547. Date of consultation: 20/06/2020.

GUTMAN, Gerald Viktorovich; MIROEDOV, Alexander Alexandrovich; FEDIN, Sergey Vladimirovich. 2001. Regional Economy Management. Publishing House "Finance and Statistics". Moscow, Russia.

HUSEYNOV, Abdurakhman Gadzhievich. 2014. "Methodological problems of defining the concept of "economic region" in the context of the allocation of the regional economy as an independent scientific direction"In: Modern problems of science and education, 3.

KAZACHENKO, Larisa Dmitrievna. 2012. "Review of scientific approaches to the definition of the category "region"'In: Bulletin-Economist. - Chita: ZabGU. Vol. 4, No. 2, pp. 169-180.

KOLMAKOVA, Evgeniya Mikaelovna. 2014. "On the role of investment planning in the socio-economic development of the territory"In: Economy. Vol.45,pp.124-128.Available online. In: https://cyberleninka. 
$\mathrm{ru} /$ article/n/o-roli-investitsionnogo-proektirovaniya-v-sotsialnoekonomicheskom-razvitii-territorii/viewer. Date of consultation: 20/06/2020.

KOLMAKOVA, Evgeniya Mikaelovna;KOLMAKOVA, Irina Dmitrievna; DEGTYAREVA, Nina Adamovna. 2018. "Spatial development of the region in the context of the strategy of socio-economic growth" In:Economic sciences. Vol. 6o, pp. 30-37. Available online. In: https:// cyberleninka.ru/article/n/prostranstvennoe-razvitie-regiona-vkontekste-strategii-sotsialno-ekonomicheskogo-rosta/viewer. Date of consultation: 20/06/2020.

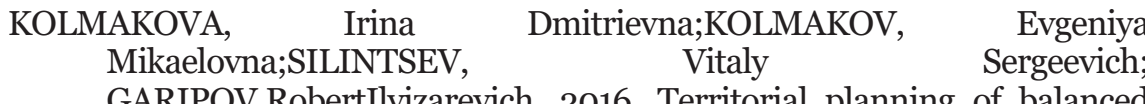
GARIPOV,RobertIlyizarevich. 2016. Territorial planning of balanced socio-ecological-economic development. Management of the balanced development of territorial systems: theory and practice. Chelyabinsk, Russia. Available online. In: https://www.elibrary.ru/item. asp?id=25995919. Date of consultation: 20/06/2020.

KVINT, Vladimir Lvovich. 2009. The Global Emerging Market: Strategic Management and Economics. Routledge.New York, USA.

KVINT, Vladimir Lvovich. 2014. Strategizing in the modern world. Federal state budgetary educational institution higher. prof. education, Russian acad. bunk bed households and state. service under the President of the Russian Federation, North-West. in-t control. IPC SZIU RANEPA. St. Petersburg, Russia.

KVINT, Vladimir Lvovich. 2016. Strategy for the Global Market Theory and Practical Applications. Routledge. New York, USA.

MANASYAN, Maxim Garnikovich. 2006. Theoretical and methodological issues of geographical research of settlement. The theory of socio-economic geography: a synthesis of modern knowledge. Collection of articles of the IV All-Russian conference. Universum. Smolensk, Russia.

OECD. 2012. Promoting Growth in All Regions. Organization for Economic Cooperation and Development. Paris, France.

OSHCHEPKOV, Victor Mikhailovich; KUZMINA, Yulia Dmitrievna. 2013. "Region as an independent economic entity"In: Perm University Bulletin. Vol. 4, No. 19, pp. 12-22.

PATOVA, Anna Georgievna;PLAKHOTNIKOVA, Maria Alexandrovna. 2020. Features of the strategic management of industrial enterprises. In the collection: Actual problems of the development of economic entities, 


\footnotetext{
Igor Valerievich Zhilkin, Aleksandr Yurievich Anisimov, Irina Anatolyevna Kubrak, Anna Victorovna Maslennikova y Vladimir Yurievich Melnikov

856 Methodological foundations of the spatial development of the region: content, conceptual instrument
}

territories and systems of regional and municipal government. Materials of the XV international scientific and practical conference, pp.271-275. Available online. In: https://www.elibrary.ru/item.asp?id=42987142. Date of consultation: 20/06/2020.

PLAKHOTNIKOVA, Maria Alexandrovna. 2019. "Business processes reengineering in the digitally dependent sectors of economy (on the example of telecommunications companies)"In: EkonomichnychasopisXXI. No. 11-12, pp.146-154.

PLAKHOTNIKOVA, Maria Alexandrovna. 2018. "Development of the Russian agro-industrial complex in the digital economy. Digitalization of the agro-industrial complex"In: Collection of scientific articles. Pp.190-192.Available online. In: https://www.elibrary.ru/ item.asp?id=36380820http://dn.tstu.ru/images/books/Agro/ Цифровизация_Т2.pdf. Date of consultation: 20/06/2020.

PLAKHOTNIKOVA, Maria Alexandrovna; KASHIRTSEVA, Anna Yurievna; ANISIMOV, Alexander Yurievich. 2019. "Features of Strategic Management of Business Processes of Telecommunication Enterprises in the Digital Economy" In: Advances in Economics, Business and Management Research. Vol. 131 "New Silk Road: Business Cooperation and Prospective of Economic Development" (NSRBCPED 2019), pp.725728.

POTAPOV, Mikhail Grigorievich. 2016. "Region - subject of the Federation: problems of understanding and correlation" In: Bulletin of the Omsk Law Academy. Vol. 3, No. 32, pp.17-22.

RONALD, Hall. 2005. "The Future of European Regional Policy: Issues Surrounding an Agenda for a Growing Europe" In: Journal of the Regional Studies Association. Vol. 39, No. 7,pp.966-971.

SIMONOVA, Lyudmila Mikhailovna; EFREMOVA, Irina Alexandrovna. 2016. "Spatial strategizing of Russia" In: Bulletin of the Tyumen State University. Socio-economic and legal research. Vol. 2, No. 4, pp. 161-174.

SUVOROVA,ArinaValerievna. 2019."Spatial development: content and features" In: Journal of New Economy.Vol. 20, No. 3, pp. 51-64. Available online. In: http://jne.usue.ru/images/download/83/4.pdf. Date of consultation: 20/06/2020.

VILNER, Mark Yakovlevich. 2016. "On the strategy of spatial development of Russia"In: Territory development management. Vol. 3, pp.14-17. Available online. In: http://www.gisa.ru/file/file3168.pdf. Date of consultation: 20/06/2020. 
VILNER, Mark Yakovlevich. 2017. "Methodological foundations for developing a spatial development strategy" In: Bulletin "Architect. 21st century" information and analytical magazine. No.1.Available online. In: https:// urtmag.ru/public/311/. Date of consultation: 20/06/2020.

VITULEVA, Tat yana Aleksandrovna. 2014. "The concept of a region as a socio-economic education"In: Bulletin of the Buryat State University. Vol.4,pp.41-46.Available online. In: https://cyberleninka.ru/article/n/ ponyatie-regiona-kak-sotsialno-ekonomicheskogo-obrazovaniya/ viewer. Date of consultation: 20/06/2020.

VORONIN, Victor Vladimirovich; SHARYGIN, Mikhail Dmitrievich. 1998. Socio-economic geography at the turn of the millennium (theoretical and methodological aspects). SGEA. Samara, Russia. Available online. In: http://library.psu.ru/files/\%20M.\%20Д.\%2оПолный\%2осписок\%20 работ.pdf. Date of consultation: 20/06/2020.

WALTER, Isard.1960. Methods of Regional Analysis: An Introduction to Regional Science. Technology Press of Massachusetts Institute of Technology and New York: John Wiley \&Sons.Boston, USA.

ZUBAREVICH, Natalia Vasilievna. 2015. "The strategy of spatial development after the crisis: from large projects to institutional modernization" In: NEA Journal. Vol. 2, No. 26, pp.226-230. 

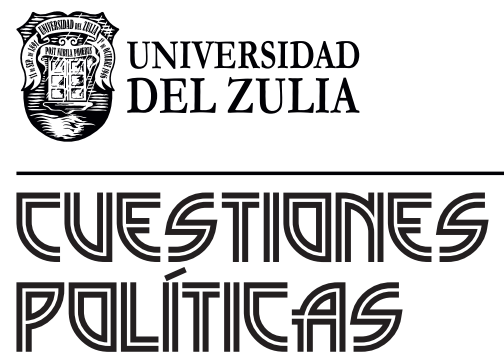

Vol. 39 N $^{\circ} 71$

Esta revista fue editada en formato digital y publicada en diciembre de 2021, por el Fondo Editorial Serbiluz, Universidad del Zulia. Maracaibo-Venezuela 